\title{
Persepsi Mahasiswa terhadap Nilai-Nilai Kejuangan Jenderal Achmad Yani
}

\author{
Student Perceptions of General Achmad Yani's Struggle Values
}

\author{
Arini Mifti Jayanti; Putri Pusvitasari ${ }^{*}$ )
}

Published online: 25 June 2021

\begin{abstract}
The aim of this research is to find out the perceptions of students of the Fakultas Ekonomi dan Sosial Universitas Jenderal Achmad Yani Yogyakarta on General Achmad Yani's Struggle Values. This study has 1 variable, namely the values of the struggle of General Achmad Yani, which will be measured for students of the Fakultas Ekonomi dan Sosial Universitas Jenderal Achmad Yani Yogyakarta. Subjects in the study ranged from \pm 200 children undergoing a teaching and learning process at the Fakultas Ekonomi dan Sosial Universitas Jenderal Achmad Yani Yogyakarta. This study aims to describe the characteristics of a population, namely students. The data analysis technique used is descriptive analysis, which is used to see the distribution of the demographic characteristics of the respondents and the variable values of General Achmad Yani's struggle.
\end{abstract}

Keyword: Perception; Fighting Values; Jenderal Achmad Yani

Abstrak: Tujuan dari penelitian ini yaitu mengetahui persepsi mahasiswa Fakultas Ekonomi dan Sosial Universitas Jenderal Achmad Yani Yogyakarta terhadap Nilai-nilai Kejuangan Jenderal Achmad Yani. Penelitian ini memiliki 1 variabel yaitu nilai-nilai kejuangan Jenderal Achmad Yani, yang mana akan diukur kepada mahasiswa Fakultas Ekonomi dan Sosial Universitas Jenderal Achmad Yani Yogyakarta. Subjek dalam penelitian berkisar antara \pm 200 anak yang sedang menjalani proses belajar mengajar di Fakultas Ekonomi dan Sosial Universitas Jenderal Achmad Yani Yogyakarta. Penelitian ini bertujuan untuk menggambarkan karakteristik suatu populasi yakni mahasiswa. Tekhnik analisis data yang digunakan adalah dengan menggunakan analisis deskriptif, analisis ini digunakan untuk melihat sebaran karakteristik demografis responden dan variabel nilai-nilai kejuangan Jenderal Achmad Yani.

Keyword: Persepsi; Nilai-nilai Kejuangan; Jenderal Achmad Yani

\section{PENDAHULUAN}

Bangsa Indonesia saat ini membutuhkan pemudapemudi yang unggul terdepan serta memiliki sikap mental semangat nasionalisme sebagai penghidup moralitas bangsa. Mahasiswa adalah pemuda-pemudi yang berperan sebagai agen perubahan, sebagai contoh serta sebagai penggerak moral dalam masyarakat. Pada era dengan

\footnotetext{
${ }^{\left.1,2^{*}\right)}$ Prodi Psikologi, Fakultas Ekonomi dan Sosial Universitas Jenderal Achmad Yani Yogyakarta

*) corresponding author

Putri Pusvitasari

Prodi Psikologi, Fakultas Ekonomi dan Sosial Universitas Jenderal Achmad Yani Yogyakarta

Email: putripusvitasari@unjaya.ac.id
}

kemajuan teknologi dan pengetahuan yang sangat pesat seperti saat ini justru moral bangsa yakni sikap mental mengenai semangat nasionalisme pada masyarakat Indonesia mulai memudar. Hal ini terlihat dari hasil statistik kriminal tahun 2019 yang diterbitkan oleh Badan Pusat Statistik menyatakan bahwa tigkat kejahatan terkait narkotik dari tahun 2017 ke tahun 2018 meningkat. Adapun dari hasil Podes 2018 bahwa perkelahian antar kelompok pada tahun 2018 merupakan perkelahian massal yang paling sering terjadi.

Semakin memudarnya moral bangsa Indonesia membuat tingkat kriminalitas dan kekisruhan yang terjadi dilingkungan masyarakat terus meningkat. Penting bagi masyarakat khususnya mahasiswa untuk kembali menghidupkan moral bangsa seperti sikap mental mengenai nasionalisme. Sikap mental mengenai semangat nasionalisme yang dimaksud adalah cinta tanah air, 
memiliki wawasan kebangsaan, serta mengembangkan nilai-nilai kejuangan dan nilai-nilai professional dari pahlawa revolusi Jenderal Achmad Yani. Dalam buku yang diterbitkan oleh Dinas Sejarah Angkatan Darat (2013) Jenderal Achmad Yani dikenal sebagai prajurit yang memiliki kepribadian istimewa seperti bakat kepemimpinan yang dibawa sejak lahir tidak dibuat atau ditempa, kemampuan menyelesaikan permasalahan dengan positif, bersifat tegas sesuai norma dan apa adanya, memiliki daya pikat dari berbagai segi baik fisik, sikap, maupun kemampuan intelektualnya dan masih banyak kepribadian dan karakter positif dari sang Jenderal.

Universitas Jenderal Achmad Yani Yogyakarta (Unjani Yogyakarta) adalah lembaga pendidikan tinggi yang bernaung dibawah panji Angkatan Darat yakni Yayasan Kartika Eka Paksi.Unjani Yogyakarta merupakan lembaga pendidikan tinggi yang memiliki tugas sebagai pelaksana pendidikan untuk menyiapkan, membentuk dan menghasilkan sumber daya manusia yang berkualitas dan berkarakter unggul dan terdepan serta mewarisi nilai-nilai kejuangan Jenderal Achmad Yani (NKJA). Para pendiri Unjani Yogyakarta menyadari sepenuhnya bahwa mahasiswa adalah agen perubahan, penggerak, pemberi contoh, dan pembaharuan dalam lingkungan sosial maka sudah seharusnya memiliki sikap mental mengenai semangat nasionalisme.Mahasiswa diyakini dapat menjadi promotor bagi hidupnya moral bangsa Indonesia, hal ini didukung oleh hasil penelitian Suryani (2015) yang menyatakan bahwa mahasiswa dapat menjadi penggerak gerakan anti korupsi di masyarakat dikarenakan mahasiswa yang akan berperan penting dalam membangun budaya dimasyarakat. Unjani Yogyakarta memiliki ciri khusus yaitu segenap penyelenggara pendidikan tinggi dan mahasiswa di Unjani Yogyakarta diharapkan selain memiliki keunggulan intelektual dibidang akademik juga mewarisi nilai-nilai kejuangan Jenderal Achmad Yani, sehingga dapat mencetak generasi intelektual yang tangguh juga menghargai keberagaman; semangat untuk bersatu;rela berkorban; pantang menyerah; memiliki jiwa kebersamaan; gotong royong; dan professional.

Unjani Yogyakarta juga memiliki keistimewaan dalam upaya untuk menghidupkan kembali moral bangsa Indonesia yang mulai memudar yakni dengan membentuk, menyiapkan dan mendidik mahasiswa yaitu dengan menjadikan nilai-nilai kejuangan Jenderal Achmad Yani sebagai bagian dari proses pendidikan dan pembelajaran dilingkungan Unjani Yogyakarta. Penerapan dan pengembangan nilai-nilai kejuangan Jenderal Achmad Yani ini dimaksudkan untuk dapat menghidupkan kembali moral bangsa yakni dengan menghasilkan sumber daya manusia yang memiliki keunggulan intelektual juga berkarakter unggul dan terdepan.Hal ini didukung dengan hasil penelitian Mujiwati (2017) bahwa lembaga pendidikan memiliki peran penting dalam pembentukan karakter generasi muda yakni sebagai penerus bangsa.

Penerapan dan pengembangan nilai-nilai kejuangan Jenderal Achmad Yani salah satunya dengan terlebih dahulu membentuk persepsi mahasiswa mengenai pentingnya NKJA sebagai bagian dari kehidupan.Persepsi yang berasal dari pengalaman-pengalama, pengetahuan dan stimulus yang diterima dapat membentuk nilai atau keyakinan seseorang terhadap suatu hal, ini lah yang menjadi dasar munculnya suatu perilaku dan pengambilan keputusan.Pembentukan persepsi mengenai pentingnya NKJA pada mahasiswa diharapkan dapat menjadikan NKJA sebagai bagian dari kehidupan mahasiswa sehingga muncul perilaku dan pengambilan keputusan yang dapat menjadikanya insan yang selain memiliki keunggulan intelektual juga berkarakter unggul dan terdepan.Dengan demikian diharapkan mahasiswa Unjani Yogyakarta dapat menjadi agen penggerak dan pembentuk moral bangsa yang sudah mulai memudar.

Fakultas Ekonomi dan Sosial (FES) Unjani Yogyakarta adalah fakultas yang baru lahir di tahun 2018 bersamaan dengan lahir nya Unjani Yogyakarta. FES unjani Yogyakarta memiliki 4 prodi yakni prodi Akuntansi, Hukum, Manajemen dan Psikologi.FES merupakan salah satu agen pembentuk dan pengembangan NKJA dilingkungan Unjani Yogyakarta, FES memiliki kesempatan yang besar untuk ikut ambil bagian dalam pembentukan dan pengembangan NKJA. Selain mendapatkan program-program pengembangan dan pembentukan NKJA oleh Universitas, FES juga memiliki keunggulan program yakni Pendidikan Karakter (PK) yang wajib diikuti oleh mahasiswa baru FES.Pendidikan karakter yang menjadi keunggulan FES, mengajarkan nilai-nilai karakter yang harus dimiliki mahasiswa agar menjadi pribadi yang unggul dan terdepan.Nilai-nilai yang diajarkan dalam pendidikan karakter sejatinya adalah bagian dari nilai-jilai kejuangan Jenderal Achmad Yani.

Peneliti memiliki minat dan ketertarikan pada topik nilai-nilai kejuangan Jenderal Achmad Yani yang menjadi pembinaan sikap dan mental dilingkungan Unjani Yogyakarta, berdasarkan hal tersebut peneliti bermaksud melakukan penelitian untuk mengetahui persepsi mahasiswa terhadap nilai-nilai kejuangan Jenderal Achmad Yani pada mahasiswa Fakultas Ekonomi dan Sosial Unjani Yogyakarta. Data yang diperoleh melalui penelitian ini diharapkan dapat menjadi landasan penyusunan program pengembangan dan pembentukan NKJA di lingkungan FES Unjani Yogyakarta.

\section{Persepsi Mahasiswa Fakultas Ekonomi dan Sosial Universitas Jenderal Achmad Yani Yogyakarta terhadap Nilai-Nilai Kejuangan Jenderal Achmad Yani}

Robbins S. P (2001) mengungkapkan bahwa persepsi adalah pemahaman seseorang terhadap stimulus yang diterima yaitu hasil interpretasi seseorang terhadap kesankesan yang diterima sehingga menghasilkan arti terhadap stimulus yang ditangkapnya.Robbins S.P (2001) juga menyatakan bahwa persepsi berhubungan erat dengan sikap, sikap yang muncul adalah akibat dari persepsi yang dimiliki. Adapun menurut Thoha\& Mifta (2007) persepsi adalah proses kognitifyang terjadi dalam diri seseorang untuk memahami pesan dan kesan yang diterima oleh inderanya.

Menurut Jalaludin (1998) persepsi adalah hasil pemahaman seseorang dari kesimpulan atas pengalamanpengalaman dan stimulus yang diterima. Sedangkan menurut Keraf (2004) suatu proses penafsiran pada stimulus yang diterima seseorang berdasarkan pengalaman-pengalaman yang dimiliki sehingga memunculkan suatu persepsi, persepsi yang terbentuk akan menimbulkan suatu reaksi.

Berdasarkan pernyataan di atas tentang definisi persepsi, dapat disimpulkan bahwa persepsi adalah proses pemahaman atau pemberian arti terhadap stimulus yang diterima seseorang, pemahaman atau pemberian arti tersebut muncul berdasarkan pengalaman yang dimiliki. Hasil persepsi dari stimulus yang diterima akan memunculkan suatu reaksi tertentu.

Nilai-nilai kejuangan Jenderal Achmad Yani dalam Universitas Jenderal Achamd Yani Yogyakarta (2018) dimaknai sebagai sikap mental mengenai semangat nasionalisme yang meliputi rasa cinta tanah air, wawasan kebangsaan serta nilai-nilai kejuangan dan nilai-nilai professional dari pahlawan revolusi Jenderal Achmad Yani. 
Jenderal Achmad Yani adalah salah satu pucuk pimpinan TNI AD dengan jabatan Kasad ke-6, Jenderal Achmad Yani memiliki kepribadian yang istimewa, hal ini dilatarbelakangi karena la tumbuh sebagai prajurit lapangan, selain itu Ia adalah prajurit yang menyukai halhal yang bersifat pragmatis dan kerap tidak menyukai pendekatan-pendekatan yang bersifat politis atau diplomatis (Dinas Sejarah Angkatan Darat, 2013)

Nilai-nilai kejuangan Jenderal Achmad Yani yang begitu istimewa sehingga baik untuk diteladani, nilai-nilai yang dimaksud adalah sebagai berikut (Universitas Jenderal Achamd Yani Yogyakarta, 2018):

1. Gigih dalam mencapai prestasi atau kemauan, yaitu memiliki kemauan kuat dalam usaha mencapai citacita dan selalu berusaha menjadi yang terdepan.

2. Jiwa kepemimpinan tinggi, yaitu memiliki kemampuan yang tinggi dalam mempengaruhi orang lain.

3. Mengutamakan kemerdekaan, yaitu mengutamakan dalam meraih hak kendali penuh atas diri dan masyarakat.

4. Pantang menyerah, yaitu dalam berbagai hal tidak mengenal putus asa

5. Patriotisme, yaitu memiliki sikap berani; pantang menyerah; dan rela berkorban demi Bangsa dan Negara. Dinas Sejarah Angkatan Darat(2003) menyatakan bahwasikap patriotism jenderal Achmad Yani dilandasi oleh jiwa nasionalisme yang tinggi, keyakinan bahwa perjuangan adalah tindakan yang tepat, kesadaran untuk berbuat yang terbaik bagi bangsa dan Negara.

6. Heroisme, yaitu keberanian membela keadilan dan kebenaran atau kepahlawanan

7. Rela dan ikhlas berkorban, yaitu menjalankan tugas yang diamahkan dengan senang hati serta menggunakan tenaga dan pikiran secara maksimal.

8. Tanpa pamrih, yaitu dalam pengabdian kepada Negara tidak mengharapkan imbalan kecuali untuk Bangsa dan Negara.

9. Berani, yaitu mau mengambil resiko demi menjalankan tugas dengan sebaik-baiknya.

10. Nasionalisme, yaitu dalam menjalankan tugas dan mencapai tujuan selalu mendasarkan diri pada kesadaran dan semangat cinta tanah air; memiliki kebanggan sebagai bangsa; memelihara kehormatan bangsa; memiliki rasa solidaritas. Adapun Dinas Sejarah Angkatan Darat (2003) menyatakan bahwa nasionalisme berasal dari kata nation yang berarti Negara, isme berarti suatu sikap ingin mendirikan Negara sesuai dengan ideologinya dan suatu sikap membela tanah air.

11. Inovatif, yaitu mampu mendayagunakan kemampuan dan keahlian untuk menghasilkan karya baru.

Adapun dalam mengembangkan nilai-nilai profesional pendidikan sebagai upaya sistematis untuk memberdayakan peserta didik menjadi insan yang unggul dan terdepan, Unjani Yogyakarta menerapkan nilai-nilai professional yaitu "ACHMAD YANI" (Universitas Jenderal Achamd Yani Yogyakarta, 2018), berikut adalah penjelasannya:

- "A", Accountable (Akuntable) mewujudkan penyelengaraan pendidikan yang dapat dipertanggungjawabkan baik secara hokum maupun masyarakat.

- "C", Creative (kreatif) menumbuhkan kreasi dan inovasi dalam penyelenggaraan pendidikan dengan mengikuti perkembangan teknologi dan informasi
- "H", Humanist(Humanis) dalam arti meiliki nilai-nilai kemanusiaan dalam menjalani hidup sehari-hari, baik sebagai mahkluk Tuhan yang Maha Esa; mahkluk individu; dan mahkluk sosial.

- "M", Morality (moral) tujuan penyelenggaraan pendidikan diarahkan untuk membentuk pribadi dengan pemikiran yang positif dan memegang teguh etika serta nilai-nilai moralitas dalam masyarakat.

- "A", Active (aktif) setiap kegiatan dalam penyelenggaraan pendidikan harus dilaksanakan secara proaktif sesuai dengan tuntutan kemajuan ilmu dan teknologi.

- "D", Discipline (disiplin) membentuk pribadi yang disiplin sesuai dengan Jenderal Achmad Yani dan TNI $A D$, sehingga dapat tercermin dalam kehidupan sehari-hari seluruh sivitas akademika dan unsur pendukungnya.

- "Y", Youth (berjiwa muda) mempunyai semnagat terbaru untuk setiap kegiatan yang dilaksanakan.

- "A", Achievement (pencapaian prestasi) mempunyai tujuan untuk mencapai prestasi dalam segala atmosfer akademik yang baik.

- "N", Normative (taat azas) penyelenggaraan pendidikan selalu berpedoman pada tata aturan yang berlaku.

- "I" Integrity (integritas) selalu memegang teguh nilainilai kejujuran dalam setiap kegiatan penyelenggaraan pendidikan tinggi.

Berdasarkan uraian di atas, peneliti ingin mengetahui persepsi mahasiswa Fakultas Ekonomi dan Sosial terhadap nilai-nilai kejuangan Jenderal Achmad Yani.Hal ini dimaksudkan untuk mengetahui pemahaman mahasiswa FES Unjani Yogyakarta terhadap nilai-nilai kejuangan Jenderal Achmad Yani. Dengan kata lain semakin baik pemahaman mahasiswa terhadap nilai-nilai kejuangan Jenderal Achmad Yani, maka dapat diduga bahwasemakin besar keinginan mahasiswa untuk menjadikan nilai-nilai kejuangan Jenderal Achmad Yani sebagai bagian dari kehidupan.

\section{METODE}

Penelitian yang ini bertujuan untuk menggambarkan karakteristik suatu populasi.Azwar (1998) menyatakan bahwa penelitian yang bertujuan untuk menggambarkan karakteristik dan fakta mengenai populasi atau bidang tertentu disebut dengan penelitian deskriptif.Penelitian ini dilakukan dengan menggunakan metode survey, data yang didapatkan bersifat deskriptif yang tidak menguji hipotesis.Metode survey menurut Syaodih (Hamdi \&Bahruddin, 2012) adalah metode yang digunakan untuk mengumpulkan data berupa pendapat dari sejumlah besar orang/kelompok/populasi terhadap topik atau isu tertentu.

Populasi dalam penelitian ini adalah seluruh mahasiswa Fakultas Ekonomi dan Sosial (FES) Universitas Jenderal Achmad Yani (UNJANI) Yogyakarta angkatan 2018 yang terdiri dari 4 program studi (Prodi Psikologi, Prodi Akuntansi, Prodi Manajemen, dan Prodi Hukum) berjumlah 143, serta mahasiswa Fakultas Ekonomi dan Sosial Unjani Yogyakarta angkatan 2019 dari 4 program studi (Prodi Psikologi, Prodi Akuntansi, Prodi Manajemen, dan Prodi Hukum) berjumlah 130 mahasiswa.

Penelitian ini menggunakan tekhnik pengumpulan data dengan accidental sampling. Tekhnik pengumpulan data dengan accidental sampling ini adalah teknik pengumpulan data dengan pemilihan sampel secara kebetulan, yang berarti peneliti secara kebetulan berjumpa dengan 
responden yang memiliki karakteristik sesuai dengan data sehingga dapat digunakan sebagai sampel (Sugiyono, 2009). Alat pengumpul data yang digunakan dalam penelitian ini adalah dengan menggunakan kuesioner, kuesioner dibuat berdasarkan indikator-indikator nilai-nilai kejuangan jenderal Achmad Yani yang disesuaikan dengan karakteristik responden yang dimaksud adalah mahasiswa Fakultas Ekonomi dan Sosial, Unjani Yogyakarta.

Tekhnik analisis data yang digunakan adalah dengan menggunakan analisis deskriptif, analisis ini digunakan untuk melihat sebaran karakteristik demografis responden dan variabel NKJA yang dipilih dari sekumpulan pertanyaan pada kuesioner dengan menggunakan explanatory factor analysis.Dalam penelitian ini, peneliti menggunakan analisis statistik deskriptif, menurut Azwar (1998) analisis statitik deskriptif adalah analisis yang bertujuan untuk memberikan deskripsi terkait respondenberdasarkan pada karakteristik kelompok responden yang diteliti dan data variable yang diperoleh. Penyajian data yang digunakan dalam penelitian ini disajikan dengan tabel distribusi frekuensi, tabel histogram, mean dan skor deviasi.

\section{HASIL PENELITIAN}

\section{Karakteristik Demografi Subjek}

Hasil pengumpulan data, dari seluruh populasi 136 mahasiswa berhasil dikumpulkan data penelitian sejumlah 117 data responden dengan hasil sebagai berikut; sekitar 65 persen responden berjenis kelamin perempuan dengan subjek sejumlah 76 mahasiswa. Selebihnya sekitar 35 persen responden berjenis kelamin laki-laki dengan subjek sejumlah 41 mahasiswa.

\section{Analisis Deskriptif Data Hasil Penelitian}

Hasil survei yang didapatkan dalam penelitian ini mengacu pada analisis deskriptif dengan membuat kategorisasi berdasarkan jawaban yang diberikan oleh responden. Ketentuan kategorisasi penelitian yang dibuat berdasarkan data nilai minimum dan maksimum di setiap aspek. Diketahui bahwa setiap aspek terdiri dari dua butir skala, dimana masing-masing skala memiliki nilai minimum 1 dan nilai maksimum 5. Oleh karena itu, jika ada dua skala dalam satu aspek nilai kejuangan Jenderal Achmad Yani, maka nilai maksimum menjadi 10 dan nilai minimum adalah 1. Berikut adalah pembagian kategorisasinya (table 1)

Table 1. kategorisasi penilaian alat ukur

\begin{tabular}{ll} 
Kategorisasi & Nilai \\
\hline Tinggi & $8-10$ \\
Sedang & $4-7$ \\
Rendah & $1-3$ \\
\hline
\end{tabular}

Persepsi Mahasiswa Fakultas Ekonomi dan Sosial Universitas Jenderal Achmad Yani Yogyakarta terhadap Nilai-Nilai Kejuangan Jenderal Achmad Yani

Berdasarkan penghitungan secara keseluruhan, 77 persen responden berada pada kategori tinggi. Sebagaimana yang diketahui angka 77 persen sudah melebihi 50 persen sehingga dapat dikatakan bahwa sebagian mahasiswa Fakultas Ekonomi dan Sosial Universitas Jenderal Achmad Yani mempersepsikan dirinya sudah mampu dalam mengaplikasikan nilai-nilai kejuangan Jenderal Achmad Yani.

Indikator Tunggal Nilai-nilai Kejuangan Jenderal Achmad Yani Mahasiswa FES

a. Gigih Mencapai Prestasi

Sekitar 97 persen responden di FES memiliki kategori tinggi dalam nilai gigih mencapai prestasi. Tidak ada sama sekali yang memiliki kategori rendah. Sedangkan sisanya sebesar 3 persen mahasiswa berada pada kategori sedang. Berdasarkan data tersebut dapat dikatakan bahwa 4ebagian besar mahasiswa FES sudah mempersepsikan dirinya memiliki nilai gigih mencapai prestasi.

b. Jiwa Kepemimpinan

Sekitar 32 persen responden di FES memiliki kategori tinggi dalam nilai jiwa kepemimpinan. Ada 1 persen dengan kategori rendah. Sedangkan sisanya sebesar 67 persen mahasiswa berada pada kategori sedang. Berdasarkan data tersebut dapat dikatakan bahwa 4 ebagian besar mahasiswa FES berada pada kategori sedang dalam mempersepsikan dirinya memiliki jiwa kepemimpinan.

c. Mengutamakan Kemerdekaan

Sekitar 88 persen responden di FES memiliki kategori tinggi dalam nilai mengutamakan kemerdekaan. Tidak ada sama sekali yang memiliki kategori rendah. Sedangkan sisanya sebesar 12 persen mahasiswa berada pada kategori sedang. Berdasarkan data tersebut dapat dikatakan bahwa 4ebagian besar mahasiswa FES sudah mempersepsikan dirinya memiliki nilai mengutamakan kemerdekaan.

d. Pantang Menyerah

Sekitar 53 persen responden di FES memiliki kategori tinggi dalam nilai pantang menyerah. Ada 2 persen dengan kategori rendah. Sedangkan sisanya sebesar 45 persen mahasiswa berada pada kategori sedang. Berdasarkan data tersebut dapat dikatakan bahwa 4 ebagian besar mahasiswa FES berada pada kategori tinggi dalam mempersepsikan dirinya memiliki nilai pantang menyerah.

e. Patriotisme

Sekitar 45 persen responden di FES memiliki kategori tinggi dalam nilai 4 ebagian $4 \mathrm{~m}$. Ada 2 persen dengan kategori rendah. Sedangkan sisanya sebesar 53 persen mahasiswa berada pada kategori sedang. Berdasarkan data tersebut dapat dikatakan bahwa 4 ebagian besar mahasiswa FES berada pada kategori sedang dalam mempersepsikan dirinya memiliki nilai 4ebagian $4 \mathrm{~m}$.

f. Heroisme

Sekitar 80 persen responden di FES memiliki kategori tinggi dalam nilai 4ebagia. Tidak ada sama sekali yang memiliki kategori rendah. Sedangkan sisanya sebesar 20 persen mahasiswa berada pada kategori sedang. Berdasarkan data tersebut dapat dikatakan bahwa 4ebagian besar mahasiswa FES sudah mempersepsikan dirinya memiliki nilai 4ebagia.

g. Rela Berkorban

Sekitar 86 persen responden di FES memiliki kategori tinggi dalam nilai rela berkorban. Tidak ada sama sekali yang memiliki kategori rendah. Sedangkan sisanya sebesar 14 persen mahasiswa berada pada kategori sedang. Berdasarkan data tersebut dapat dikatakan bahwa 4 ebagian besar mahasiswa FES sudah mempersepsikan dirinya memiliki nilai rela berkorban. 
h. Tanpa Pamrih

Sekitar 90 persen responden di FES memiliki kategori tinggi dalam nilai tanpa pamrih. Tidak ada sama sekali yang memiliki kategori rendah. Sedangkan sisanya sebesar 10 persen mahasiswa berada pada kategori sedang. Berdasarkan data tersebut dapat dikatakan bahwa 5 ebagian besar mahasiswa FES sudah mempersepsikan dirinya memiliki nilai tanpa pamrih.

i. Berani

Sekitar 94 persen responden di FES memiliki kategori tinggi dalam nilai berani. Tidak ada sama sekali yang memiliki kategori rendah. Sedangkan sisanya sebesar 6 persen mahasiswa berada pada kategori sedang. Berdasarkan data tersebut dapat dikatakan bahwa 5ebagian besar mahasiswa FES sudah mempersepsikan dirinya memiliki nilai pemberani.

j. Nasionalisme

Sekitar 96 persen responden di FES memiliki kategori tinggi dalam nilai nasionalisme. Tidak ada sama sekali yang memiliki kategori rendah. Sedangkan sisanya sebesar 4 persen mahasiswa berada pada kategori sedang. Berdasarkan data tersebut dapat dikatakan bahwa 5 ebagian besar mahasiswa FES sudah mempersepsikan dirinya memiliki nilai nasionalisme.

k. Inovatif

Sekitar 85 persen responden di FES memiliki kategori tinggi dalam nilai inovatif. Tidak ada sama sekali yang memiliki kategori rendah. Sedangkan sisanya sebesar 15 persen mahasiswa berada pada kategori sedang. Berdasarkan data tersebut dapat dikatakan bahwa 5ebagian besar mahasiswa FES sudah mempersepsikan dirinya memiliki nilai inovatif.

\section{PEMBAHASAN}

Penelitian ini dilakukan guna untuk memberikan gambaran terkait persepsi mahasiswa Fakultas Ekonomi dan Sosial Unjani Yogyakarta. Serta memberikan gambaran terkait pengaruh persepsi mahasiswa terhadap kemauan untuk menjadikan nilai-nilai kejuangan Jenderal Achmad Yani sebagai bagian dari kehidupanya. Persepsi menurut Robbins S.P (2001) bahwa persepsi berhubungan erat dengan sikap, sikap yang muncul adalah akibat dari persepsi yang dimiliki seseorang. Persepsi adalah proses pemahaman atau pemberian arti terhadap stimulus yang diterima seseorang, pemahaman atau pemberian arti tersebut muncul berdasarkan pengalaman yang dimiliki. Hasil persepsi dari stimulus yang diterima akan memunculkan suatu reaksi tertentu. Dengan penelitian ini maka dapat ditemukan seberapa besar pengaruh persepsi mahasiswa terhadap kemauanya untuk menjadikan nilai-nilai kejuangan Jenderal Achmad Yani sebagai salah satu dasar untuk bereaksi terhadap suatu hal.

Pendekatan yang digunakan dalam penelitian ini adalah pendekatan kuantitatif. Metode pengumpulan data penelitian menggunakan alat ukur berupa skala persepsi mahasiswa terhadap nilai-nilai kejuangan Jenderal Achmad Yani. Subjek dalam penelitian ini adalah mahasiswa yang berjenis kelamin perempuan dan laki-laki sejumlah 117 subjek. Pembagian subjek dilakukan secara acak dengan sasaran subjek adalah mahasiswa Fakultas Ekonomi dan Sosial Universitas Jenderal Achmad Yani Yogyakarta. Hasil pengumpulan data dari 117 subjek adalah sebagai berikut: dari total keseluruhan subjek sejumlah 117 subjek, 36,8\% subjek memilih jawaban Sangat Sesuai, 46\% subjek memilih jawaban Sesuai, 13,9\% subjek memilih jawaban Kurang Sesuai, 2,3\% memilih jawaban Tidak Sesuai, dan 0,9\% memilih jawaban Sangat Tidak Sesuai. Hal ini dapat diartikan bahwa sebesar 82,8 \% subjek, sudah mengaplikasikan nilai-nilai kejuangan Jenderal Achmad Yani. Berdasarkan indikator yang paling dominan dengan pilihan Sangat Sesuai adalah gigih dalam mencapai prestasi, yaitu sebesar 65,4\%. Pada urutan kedua, indikator yang dominan dengan pilihan Sangat Sesuai adalah mengutamakan kemerdekaan, yaitu sebesar 53,8\%. Kemudian di urutan ketiga, indikator yang dominan dengan pilihan Sangat Sesuai adalah nasionalisme, yaitu sebesar 49,6\%. Pada urutan keempat, indikator yang dominan dengan pilihan Sangat Sesuai adalah rela berkorban, yaitu sebesar 44,9\%. Pada urutan kelima, indikator yang dominan dengan pilihan Sangat Sesuai adalah heroisme, yaitu sebesar $37,6 \%$. Pada urutan keenam, indikator yang dominan dengan pilihan Sangat Sesuai adalah inovatif, yaitu sebesar $34,2 \%$. Setelah itu, pada urutan ketujuh, indikator yang dominan dengan pilihan Sangat Sesuai adalah berani, yaitu sebesar $33,8 \%$. Kemudian pada urutan kedelapan, indikator yang dominan dengan pilihan Sangat Sesuai adalah tanpa pamrih, yaitu sebesar $32,1 \%$. Pada urutan kesembilan, indikator yang dominan dengan pilihan Sangat Sesuai adalah patriotisme, yaitu sebesar $24,3 \%$. Pada urutan kesepuluh, indikator yang dominan dengan pilihan Sangat Sesuai adalah pantang menyerah, yaitu sebesar $21,4 \%$. Dan yang terakhir pada urutan kesebelas, indikator yang dominan dengan pilihan Sangat Sesuai adalah jiwa kepemimpinan, yaitu sebesar $8,1 \%$. Sedangkan sisanya dalam setiap indikator, subjek memilih pilihan jawaban yang lain.

\section{KESIMPULAN DAN REKOMENDASI}

Berdasarkan hasil analisis dapat disimpulkan bahwa dari total keseluruhan subjek sejumlah 117 subjek, 36,8\% subjek memilih jawaban Sangat Sesuai, 46\% subjek memilih jawaban Sesuai, 13,9\% subjek memilih jawaban Kurang Sesuai, 2,3\% memilih jawaban Tidak Sesuai, dan 0,9\% memilih jawaban Sangat Tidak Sesuai. Hasil analisis menunjukkan bahwa 82.8 \% subjek telah mengaplikasikan nilai-nilai kejuangan Jenderal Achmad Yani Yogyakarta dan 17.2\% NKJA belum terimplementasikan.

Implikasi dari penelitian ini adalah diharapkan agar para mahasiswa, dapat diberikan edukasi lebih mendalam lagi mengenai NKJA sehingga mahasiswa dapat mengimplemantasikan dalam kehidupan sehari-hari dan menjadi kebiasaan yang pada akhirnya muncul karakter yang baru. Selanjutnya bagi peneliti yang akan melakukan penelitian dengan variabel terkait, sebaiknya memperhatikan variabel lain yang lebih meluas agar diperoleh gambaran penelitian yang lebih komprehensif.

\section{Conflict of Interests Statement}

The authors declared that no potential conflicts of interests with respect to the authorship and publication of this article.

\section{DAFTAR PUSTAKA}

Azwar, S. (1998). Metode Penelitian. Yogyakarta: Pustaka Pelajar 
Badan Pusat Statistik. (2019). Statistik Kriminal 2019. Badan Pusat Statistik

Dinas Sejarah Angkatan Darat. (2013). Achmad Yani, Prajurit Patriot Sejati. Bandung: Dinas Sejarah Angkatan Darat

Hamdi A.S \& Bahruddin.E. (2012).Metode Penelitian Kuantitatif Aplikasi dalam Pendidikan. Yogyakarta: Penerbit Deepublish

Jalaludin.R.(1998).Pembinaan Kemampuan. Jakarta: Erlangga

Keraf.G. (2004).Argumentasi dan Narasi.Jakarta : Gramedia Pustaka Utama.

Mujiwati.(2017). Peran Pendidikan Karakter Dalam Pembangunan Karakter Bangsa.Jurnal Ilmiah Edukasi \& Sosial. Vol 8 No 2

Robbins. S.P. (2001).Perilaku Organisasi, Edisi Bahasa Indonesia. Jakarta: PT Prenallindo

Sugiyono, (2009).Metode Penelitian Kuantitatif, Kualitatif dan $R \& D$. Bandung : Alfabeta

Suryani, I. (2015). Penanaman Nilai-Nilai Anti Korupsi di Lembaga Pendidikan Tinggi Sebagai Upaya Preventif Pencegahan Korupsi.Jurnal Visi Komunikasi. Vol 14.No.02

Thoha \& Mifta.(2007). Perilaku Organisasi, Konsep Dasar dan Aplikasinya. Jakarta: PT Raja Grafindo.

Universitas Jenderal Achamd Yani Yogyakarta.(2018).Sejarah Pendirian Universitas Jenderal Achamd Yani Yogyakarta. Yogyakarta: Biro Kerjasama, Promosi, dan Publikasi. 